\title{
Analysis of executive coaching effectiveness: a study from the coachee perspective
}

\author{
Análisis de la eficacia del coaching ejecutivo: un \\ estudio desde la perspectiva del coachee
}

\author{
EnEKa Albizu ${ }^{1}$ \\ IZASKUN REKALDE ${ }^{2}$ \\ JON LANDETA ${ }^{2}$ \\ Pilar Fernández-Ferrín ${ }^{3}$ \\ University of the Basque Country (UPV/EHU) (España)
}

Recibido el 18 de diciembre de 2017, aceptado el 26 de julio de 2018

Publicado online el 25 de enero de 2019

$\mathrm{N}^{\circ}$ de clasificación JEL: M12, M53

DOI: $10.5295 /$ cdg. $170876 \mathrm{ea}$

\begin{abstract}
:
Executive coaching has become one of the principal leadership development strategies of our time. However, this is a field of HRD that has been discussed far more often in professional than academic literature and further research is required. This work analyses the relation existing between the main explanatory factors of executive coaching effectiveness and the different types of results that can be achieved. This study also provides an empirical test of the effectiveness of executive coaching using the first three levels of Kirkpatrick's evaluation model (1975). Responses from 176 executives are analyzed, assessing their perceptions of their latest experience of executive coaching. Structural modelling is used to match factors affecting the success of executive coaching to its results. The resulting model highlights the influence exercised by the coach, and to a lesser extent the coachee and the process, on coachee satisfaction. It also shows how the coach influences the coachee's learning. The results also suggest that there is a positive relationship between satisfaction, learning and behavioral change, as Kirkpatrick suggests. The development of a final focus group, in which human resources managers, coachees and coaches took part, contributed to improvements in the discussion and interpretation of the results. In the light of these results, the implications for the professional and academic area are considered.
\end{abstract}

Keywords:

Executive coaching, executive development, factors, results, effectiveness.

1 Faculty of Industrial Relations. B ${ }^{\circ}$ Sarriena s/n. 48940 Leioa (Spain).eneka.albizu@ehu.eus

2 Faculty of Economics and Business Studies. Avda Lehendakari Agirre, 82. 48015. Bilbao (Spain). izakun. rekalde@ehu.eus; jon.landeta@ehu.eus

3 Faculty of Economics and Business Studies. C/ Comandante Izarduy 23, 01006 Vitoria-Gasteiz (Spain). pilar. fernandezf@ehu.eus 


\section{Resumen:}

El coaching ejecutivo se ha convertido en una de las principales estrategias de desarrollo directivo de nuestros tiempos. Sin embargo, es un campo del área de desarrollo de RR.HH. en el que predomina la literatura profesional sobre la académica y que está necesitado de más investigación. Este trabajo analiza la relación existente entre los principales factores explicativos de la eficacia del coaching ejecutivo y los diferentes tipos de resultados que se pueden alcanzar. Este estudio aporta además una prueba empírica de la eficacia del coaching ejecutivo utilizando los tres primeros niveles del modelo de evaluación de Kirkpatrick (1975). Se analizan las respuestas de 176 directivos valorando sus percepciones acerca de su última experiencia de coaching ejecutivo. Se utiliza modelización estructural para relacionar factores que inciden en el éxito del coaching ejecutivo con los resultados del mismo. El modelo resultante pone de relieve la influencia que ejercen el coach, y en menor medida el coachee y el proceso, sobre la satisfacción del coachee. También muestra cómo se materializa la influencia ejercida por el coach sobre los aprendizajes del coachee. Asimismo, los resultados sugieren la existencia de una relación positiva entre satisfacción, aprendizaje y cambio de comportamiento, tal y como sugiere Kirkpatrick. Un focus group final en el que han tomado parte directivos de recursos humanos, coachees y coaches ha contribuido a la mejora de la discusión e interpretación de los resultados. A la luz de estos resultados, se plantean implicaciones para el ámbito profesional y académico.

\section{Palabras clave:}

Coaching ejecutivo, desarrollo directivo, factores, resultados, eficacia. 


\section{INTRODUCTION}

Executive coaching (EC) is a method for encouraging executives' personal and professional growth, providing them with permanent transformative learning that impacts one or more of their visible forms of behavior, in turn influencing the behavior and performance of their direct collaborators. The main purpose of this method of executive training and development is therefore to encourage change in the way executives behave in their work (Lewis-Duarte and Bligh 2012).

Unlike other forms of organizational coaching, in EC the coachee is a company executive -with responsibilities in achieving organizational goals- while the coach is usually an external expert consultant with no direct ties to the organization. The process is performed through a one-to-one relationship based on mutual trust and respect. EC focuses on achieving a specific goal, established by common agreement between coach and coachee. It gives executives an opportunity to observe their own conduct in the mirror of the coach's feedback and to learn to improve their individual performance in an atmosphere of privacy, non-judgement and confidentiality (Jones et al. 2016).

EC has become increasingly important in the business world as a technique for executive training and development (Joo 2005; MacKie 2014; Theeboom et al. 2014). In the light of published results and experiences, it appears to be effective and to improve managerial behavior (Compasspoint 2003; Luthans and Peterson 2003; Wasylyshyn 2003; Kombarakaran et al. 2008; De Haan et al. 2011; Bozer et al. 2014a; MacKie 2014; Theeboom et al. 2014; Grover and Furnham 2016; Jones et al. 2016; Rekalde et al. 2017). However, more research is required to reinforce its theoretical underpinnings; in particular, its validity needs to be tested in rigorous empirical studies (Ely et al. 2010; De Haan et al. 2013; Grant 2013; Bozer et al. 2014a; Jones et al. 2016). This problem is reflected in a scarcity of specific evaluation scales and models for EC (Joo 2005; Hagen and Peterson 2014; Grover and Furnham 2016; Kovacs and Corrie 2016; Osatuke et al. 2016).

The purpose of this study is to provide an empirical test of coaching effectiveness from the coachee's perspective by analyzing the relationship between the main explanatory factors of executive coaching (EC) and the different types of result that can be achieved, using the evaluation model designed by Kirkpatrick (1975). This study makes various contributions to scientific research into EC. On the one hand, it determines the relative influence of the different factors on the success of EC while providing a model that measures the impact of an EC intervention. On the other hand, the results of the study offer fresh empirical evidence of EC's validity for generating satisfaction and learning among participating executives and for changing the specific forms of behavior addressed in the process. Finally, this study shows Kirkpatrick's evaluation model (1975) to be a valid theoretical and empirical reference for assessing the effectiveness of EC, based on coachees' perception of their satisfaction, learning and change of behavior deriving from a EC process.

The document is organized as follows. We first develop the conceptual framework, deduce the hypotheses to be tested and present the methodology and results. We then discuss the results, examining the implications for firms and coaches. Finally, we set out our conclusions and propose future lines of research. 


\section{CONCEPTUAL FRAMEWORK AND HYPOTHESES}

The basis of the conceptual model presented here (see Figure 1) is an evaluation framework devised expressly for executive coaching by Ely et al. (2010) and Ely and Zaccaro (2011). The model comprises two parts: formative and summative evaluation. Because of the dynamic nature of coaching, a formative evaluation is required that will identify the relative impact of the variables influencing EC effectiveness. This will enable elements of the process to be altered and refined, in order better to meet the client's specific needs. According to the proposed model and other texts (i.e., Joo 2005; Passmore and Fillery-Travis 2011; Bozer et al. 2014b; Rekalde et al. 2015; Blackman et al. 2016), the main variables conditioning the result of the coaching experience are: the performance of the coach, the readiness of the coachee, the relationship between coach and coachee, the characteristics of the coaching process and the organizational context. The hypothesized model therefore proposes a formative evaluation of the 'coach', 'coachee', 'relationship' and 'process' variables, analyzing their influence on coachee satisfaction, which impacts favorably on the results of the intervention.

The hypothesized model also includes a summative evaluation of the effectiveness of EC, based on the first three levels of Kirkpatrick's model (1975). This model "represents a logical organization and progression of outcomes" (Jones et al. 2016, p. 5) starting from basic individual reactions to learning, changes in behavior and, finally, organizational results. In accordance with the first three levels of the model, the results of EC are thus broken down into three categories: 'satisfaction' (immediate reaction to the coaching process), 'learning' and behavioral change ('behavior'). The possible relationship between these three categories is analyzed.

Figure 1

\section{Hipothesized model of executive coaching effectiveness}

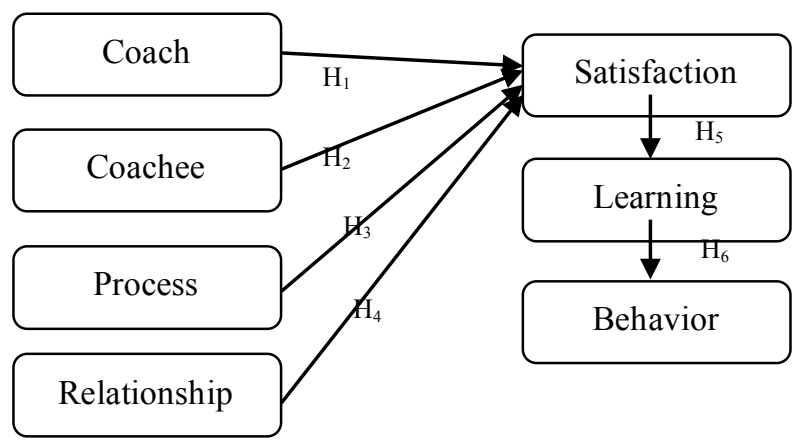

Source: Own work, from contributions by different authors. 


\subsection{Variables explaining coachees' satisfaction with the coaching process}

The coach's performance is critical to the success of the coaching process. The coach should possess certain skills that will contribute to the good outcome of the process, having a positive impact on coachee perception of the effectiveness of coaching (De Haan et al. 2013). Among these aptitudes, the literature particularly highlights communication skills (Hall et al. 1999; Gyllensten and Palmer 2006; De Haan et al. 2011; Rekalde et al. 2015), since it is reasonable to presume that coaches who contribute to a satisfactory coaching experience are competent at communicating with the coachee (verbal and non-verbal communication, active listening, assertiveness, etc.). Other authors mention the ability to generate trust amongst coachees (Gyllensten and Palmer 2006; Jones and Spooner 2006; Rekalde et al. 2015; Bozer at al. 2014a). This is essential in facilitating individuals to reveal as much about their concerns as possible, so that the coach can orient actions as appropriate for each coachee's development. Another critical aspect is the coaches' commitment to both the process and the coachee (Hall et al. 1999; Kilburg 2001; Rekalde et al. 2015). This enables them to demand the most from themselves and from their coachees in order to achieve the goals of the process. These desirable forms of behavior in coaches are in line with studies by Ellinger et al. (2003) and Kim et al. (2013), which relate them to coachee satisfaction. Thus, we propose:

Hypothesis 1. Coachees' perception of the coach's performance is positively related to their satisfaction with the EC experience.

There is a wealth of research confirming the importance of motivating aspects to the achievement of coachee's EC goals (Kilburg 2001; Wasylyshyn 2003; De Haan et al. 2013; Rekalde et al. 2015). Wasylyshyn (2003) suggests that the most positive coaching outcomes are found amongst coachees who feel motivated to learn and are willing to adapt their behavior and attitudes to achieve success. Lambert and Barley (2002) suggest that coachee willingness is the most important factor for bringing about change, and may be responsible for a variation of up to 40 percent in the results. Findings by Tracey et al. (2001) suggest that there is a direct and positive relationship between pretraining motivation and reactions (both affective reactions and utility reactions). In any event, motivation is not in itself enough for undertaking a process of personal change (in attitudes and behavior); the executive must also make a commitment (Kilburg 2001; Feldman and Lankau 2005; Joo 2005; Kombarakaran et al. 2008; Rekalde et al. 2015) to the actions agreed with the coach if the proposed development targets are to be met. The coachees' sense of achievement, stemming from a drive to learn new forms of behavior, will increase their perception of the effectiveness of the coaching, foreseeably inducing a greater degree of self-satisfaction. Thus, we propose:

Hypothesis 2. Coachees' perception of their own readiness is positively related to their satisfaction with the EC experience.

There is wide consensus as to how a typical session might be described (Bachkirova et al. 2015). One of the cornerstones of any coaching process is feedback (Olivero et al. 
1997; Hall et al. 1999; Thach 2002; Wasylyshyn 2003; Feldman and Lankau 2005; Jones and Spooner 2006; Kombarakaran et al. 2008; Bozer et al. 2014b; Rekalde et al. 2015). Feedback involves the coach presenting the coachee with the results obtained from the data compiled on the latter's performance. Subsequent sessions provide continuous feedback on the coachees' behavior in different situations that may arise during the process, thus increasing their motivation and involvement (Smither et al. 2003), in the expectation that this will contribute to their satisfaction with the process.

Many authors (Olivero et al. 1997; Smither et al. 2003; Joo 2005; Gessnitzer and Kauffeld 2015; Rekalde et al. 2015) also argue that target-setting is essential to the success of the EC process. Kilburg (2001) stresses the establishment of realistic target-linked expectations. Gessnitzer and Kauffeld (2015) find that client-initiated agreement on goals/tasks is positively related to coaching success. Olivero et al. (1997) suggest that target-setting not only contributes directly to the progress of the process itself. This, they argue, actually enables coachees to be aware of when these goals are being fulfilled, thus increasing their self-perception of effectiveness, as well as their self-confidence and levels of effectiveness. This all adds to coachee perception of the satisfactoriness of the EC process.

Length is another aspect that may be decisive in determining satisfaction with a coaching process and its effectiveness. The duration of a program is partly defined by the number of sessions in the process. Although it would be impossible to specify the ideal number of EC sessions, given that it is an individualized process, studies such as Thach (2002) indicate that effectiveness increases significantly with a greater number of sessions. However, some studies also suggest that while satisfactory results occur in the first months, if an EC process goes on too long, it can lead to diminishing returns (Luthans and Peterson 2003). While expectations of effectiveness, defined in terms of behavioral change, are likely to condition the coachee's immediate satisfaction with the coaching process, the number of sessions taken might influence the subject's degree of satisfaction. Thus, we propose:

Hypothesis 3. Coachees' perception of the process carried out is positively related to their satisfaction with the EC experience.

Because EC is an interpersonal process, aspects inherent to the singular relationship between coach and coachee are decisive to the success of the experience (Kilburg 2001; Gyllensten and Palmer 2006; Baron and Morin 2009a; Boyce et al. 2010; Ely et al. 2010; De Haan et al. 2011; De Haan et al. 2013; Gan and Chong 2015; Rekalde et al. 2015; De Haan et al. 2016). In a recent survey, Carter et al. (2017) show that a non-satisfactory relationship could affect coachee perceptions on coaching effectiveness and result in even poorer coaching outcomes. The quality of the relationship (Lopez, 2017) — based on empathy, mutual trust (transparency, honesty, reciprocity), openness and support in accordance with the client's needs - contributes to a positive result in any form of intervention to reinforce behavioral change. Kilburg (1997) adds respect, consideration and understanding for the complexities of the client's experience to the list of characteristics of a successful coaching relationship. Gyllensten and Palmer (2006) suggest that empathy and unconditional mutual respect are major lubricants in generating a satisfactory relationship. Thus, we propose: 
Hypothesis 4. Coachees' perception of the relationship developed is positively related to their satisfaction with the EC experience.

\subsection{Relation between different types of coaching results}

Sitzmann et al. (2008) find that reactions (process satisfaction) predict changes in trainees' motivation and self-efficacy (learning). Some studies suggest that satisfactory training experiences have positive consequences on employees' attitudes, including commitment toward the organization and motivation at work (Rhoades and Eisenberger 2003) and on learning-transfer (Alliger and Janak 1989; Pershing and Pershing 2001). Russ $\square$ Eft et al. (2005) demonstrate that negative reactions lead to poorer learning results. A study by Lim and Morris (2006) suggests that there are different variables in trainee characteristics, including general satisfaction, satisfaction with learning content and satisfaction with the instructor. These are closely correlated to both the pupil's perception of the learning and to transferred learning, taken independently and together. Tsai et al. (2007) suggest that employees' satisfaction has a positive influence on their commitment to learning. Joo (2005) and Bozer et al. (2014b) argue that the immediate results -including satisfaction with the process - are precursors to more long-term outcomes (learning and behavioral change). One may therefore assume that an executive who is satisfied with the EC process will be better positioned to internalize learning. We therefore propose:

Hypothesis 5. Coachees' satisfaction with the EC experience is positively related to their perceived learning.

The knowledge, skills and (fundamentally) the changes in attitudes developed through a learning process such as EC, lay the groundwork for permanent and observable changes in coachees' behavior. One of the main purposes of EC is for the production of learning to facilitate a transformation in managerial behavior. Ely et al. (2010) divide the learning resulting from an EC process into two types: cognitive and emotional. Cognitive-level learning includes 'self-awareness', or a better knowledge of oneself and of how one's own behavior affects others, and vice-versa. Noe and Wilk (1993) suggest that enhanced self-awareness is related to improved commitment to development activities and high performance. The cognitive level of learning includes 'cognitive flexibility', which is associated with the executives' capacity to explore different approaches and cognitive frameworks that enable greater openness to change and to managing adaptation to new circumstances. Studies by Jones and Spooner (2006) and Finn et al. (2007) show that executives who have participated in EC processes show a greater propensity to engage in new forms of behavior than those who have not.

Emotional learning includes coachees' 'self-efficacy' and changes in attitude. 'Self-efficacy' refers to the executives' enhanced confidence, which allows them to apply their recently acquired skills (Kraiger et al. 1993). De Haan et al. (2013) found that general self-efficacy predicts coaching effectiveness. The positive relationship between self-efficacy and high-performance behavior has been established in empirical research by Stajkovic and Luthans (1997) and endorsed by studies as by CompassPoint (2003). Thus, we propose: 
Hypothesis 6. Coachees' perception of their learning in the EC experience is positively related to their own perceived behavioral change.

\section{METHODOLOGY}

\subsection{Sample and data collection}

The population of this survey comprises Spanish executives who have undergone an EC process with a coach certified by any of the recognized associations in Spain. In order to locate coachees who were willing to participate in the study, these organizations sent letters to their contacts on behalf of the research team, inviting them to take part in the study. The valid sample is made up of 176 cases of executives who had participated in at least one coaching process; their responses refer to the most recent EC process they had engaged in. Data was collected between January and June 2014 by means of an electronic survey of executive coachees.

The 176 responses received were all considered valid for analysis. The coachees involved in the survey worked or had responsibilities in the human resources area $(38.1 \%)$; were area or project leaders or middle managers (19.3\%); or were chief executives, presidents or managing directors $(17.6 \%)$ or functional managers $(16.5 \%)$.

Respondents were $57 \%$ male and $43 \%$ female and were aged between 26 and 65 . The average age was $44.35(\mathrm{SD}=6.72)$. On average, the most recent coaching process in which they had taken part (the basis for their answers) was 9.56 sessions long ( $\mathrm{SD}=16.31$, Me$\operatorname{dian}=6.00)$.

\subsection{Measurements}

To test the influence of the independent variables in the model, this study uses the measurements recently provided by Rekalde et al. (2015) using a Hybrid Delphi process, given that the cultural, geographical and time context of their study is similar to that of the expert sample group consulted in this research. They obtained a list of indicators grouped into five categories, sorted by their capacity to influence the success of a coaching process. This study has taken the highest-scoring indicators from the 'coach', 'coachee', 'process' and 'relationship' categories as indicators of the explanatory variables of the model.

In order to design the scales used to measure the results, we used the work by Ely and Zaccaro (2011) to complete measurements of coachee satisfaction. Studies by Chen et al. (2001) and Luthans and Peterson (2003) contributed to making measurements of coachee learning more complete, and the measures proposed by Ely and Zaccaro (2011) were adapted to determine behavioral change.

The items or indicators covered in this work (see Table 1) were assessed using a seven-point scale. All indicators of the results variables ('satisfaction', 'learning' and 'behavior') and indicator V1 of the 'coach' variable were measured on a Likert scale ( $1=$ strongly disagree, $7=$ strongly agree). The remaining indicators were also measured on a seven-point scale by degree of presence ( 1 = strongly absent, $7=$ strongly present $)$. 
Table 1

Variables, indicators, descriptive results, and measurement reliability

\begin{tabular}{|c|c|c|c|}
\hline \multirow{2}{*}{ VARIABLES* } & \multirow{2}{*}{ INDICATORS } & \multicolumn{2}{|c|}{ Descriptive } \\
\hline & & Average & SD \\
\hline \multirow{3}{*}{$\begin{array}{l}\text { Coach } \\
\text { CA: } 0.803 \\
\text { CR: } 0.766 \\
\text { AVE: } 0.521\end{array}$} & V1. The coach has conveyed and generated trust in you & 6.062 & 0.986 \\
\hline & $\begin{array}{l}\text { V2. Coach's competency in handling communication skills } \\
\text { (active listening, assertiveness, analysis and synthesis...) }\end{array}$ & 6.034 & 0.944 \\
\hline & V3. Coach's commitment to the process & 6.194 & 0.987 \\
\hline \multirow{2}{*}{$\begin{array}{l}\text { Coachee } \\
\text { CA: } 0.836 \\
\text { CR: } 0.839 \\
\text { AVE: } 0.722\end{array}$} & V4. Your own need (to learn, develop yourself or be well) & 6.034 & 1,003 \\
\hline & V5. Your commitment to the process & 6.029 & 0.962 \\
\hline \multirow{3}{*}{$\begin{array}{l}\text { Process } \\
\text { CA: } 0.874 \\
\text { CR: } 0.876 \\
\text { AVE: } 0.639\end{array}$} & V6. Feedback received from the coach & 5.823 & 1.123 \\
\hline & $\begin{array}{l}\text { V7. Suitable duration in terms of time or number of } \\
\text { sessions }\end{array}$ & 5.274 & 1.302 \\
\hline & $\begin{array}{l}\text { V8. Focus on the setting and scope of goals (clear target- } \\
\text { setting, permanent orientation towards specific targets) }\end{array}$ & 5,450 & 1,184 \\
\hline \multirow{4}{*}{$\begin{array}{l}\text { Relationship } \\
\text { CA: } 0.790 \\
\text { CR: } 0.791 \\
\text { AVE: } 0.562\end{array}$} & V9. Coach's empathy with you & 6.259 & 0.898 \\
\hline & $\begin{array}{l}\text { V10. Authenticity in the relationship (transparency, } \\
\text { honesty, lack of hypocrisy) }\end{array}$ & 6.250 & 0.935 \\
\hline & $\begin{array}{l}\text { V11. Unconditional mutual respect (respectful accep- } \\
\text { tance of the other party, as they show themselves) }\end{array}$ & 6.434 & 0.806 \\
\hline & $\begin{array}{l}\text { V12. Balance between distance and proximity in the } \\
\text { relationship between the coach and you (suitable com- } \\
\text { bination of technical rigor and support conduct) }\end{array}$ & 5.907 & 1.010 \\
\hline \multirow{4}{*}{$\begin{array}{l}\text { Satisfaction } \\
\text { CA: } 0.911 \\
\text { CR: } 0.914 \\
\text { AVE: } 0.729\end{array}$} & V13. I am satisfied with the coach's performance & 6.085 & 0.991 \\
\hline & V14. I am satisfied with my own performance & 5.631 & 1.011 \\
\hline & $\begin{array}{l}\text { V15. I am satisfied with the relationship developed } \\
\text { with the coach }\end{array}$ & 6.081 & 0.889 \\
\hline & $\begin{array}{l}\text { V16. I am satisfied in overall terms with the coaching } \\
\text { experience }\end{array}$ & 5.897 & 1.067 \\
\hline \multirow{6}{*}{$\begin{array}{l}\text { Learning } \\
\text { CA: } 0.941 \\
\text { CR: } 0.938 \\
\text { AVE: } 0.715\end{array}$} & $\begin{array}{l}\text { V17. I am more aware of my strengths and areas for } \\
\text { improvement }\end{array}$ & 5.773 & 1.134 \\
\hline & $\begin{array}{l}\text { V18. I am more aware of the impact my behavior has } \\
\text { on others }\end{array}$ & 5.914 & 1.055 \\
\hline & $\begin{array}{l}\text { V19. I am more aware of the impact the behavior of } \\
\text { others has on me }\end{array}$ & 5.772 & 1.117 \\
\hline & $\begin{array}{l}\text { V20. I am more predisposed to make changes in my } \\
\text { behavior }\end{array}$ & 5.908 & 1.096 \\
\hline & $\begin{array}{l}\text { V21. I have acquired knowledge, skills and abilities } \\
\text { that will help me as I progress in my professional } \\
\text { career }\end{array}$ & 5.659 & 1.222 \\
\hline & V22. I feel more qualified to face challenges in my work & 5.701 & 1.124 \\
\hline
\end{tabular}




\begin{tabular}{|l|l|l|l|}
\hline & V23. I have changed certain observable behaviors & 5.491 & 1.108 \\
\cline { 2 - 4 } & V24. The behaviors I have changed remain over time & 5.471 & 1.074 \\
\hline & $\begin{array}{l}\text { V25. The change in my behavior has been perceived by } \\
\text { people under my responsibility }\end{array}$ & 5.235 & 1.132 \\
\cline { 2 - 4 } & $\begin{array}{l}\text { V26. The change in my behavior has been perceived by } \\
\text { my colleagues of the same hierarchical level }\end{array}$ & 5.113 & 1.255 \\
\cline { 2 - 4 } $\begin{array}{l}\text { Behavior } 0.953 \\
\text { CR: } 0.939 \\
\text { AVE: } 0.659\end{array}$ & $\begin{array}{l}\text { V27. The change in my behavior has have been percei- } \\
\text { ved by my direct superior }\end{array}$ & 5.080 & 1.347 \\
\cline { 2 - 4 } & $\begin{array}{l}\text { V28. I perform management tasks more effectively } \\
\text { V29. My behavior profile is better suited to the } \\
\text { company's needs }\end{array}$ & 5.392 & 1.145 \\
\cline { 2 - 4 } & $\begin{array}{l}\text { V30. I adapt better to changes (adaptation to change } \\
\text { with less stress, adaptation of your personal approach } \\
\text { to new situations, adaptation to new teams, processes, } \\
\text { procedures, etc.) }\end{array}$ & 5.558 & 1.162 \\
\hline
\end{tabular}

*Cronbach's alpha (CA); composite reliability (CR); average variance extracted (AVE).

Source: Own work.

\subsection{Reliability and validity of measuring scales}

The questionnaire was pre-tested by 15 EC practitioners (coaches, coachees and HR managers) to measure the content validity of the questionnaire as a whole. Reliability of the measuring scales was assessed in three ways: Cronbach's alpha coefficient, composite reliability analysis and the variance extracted index. For the first analysis the SPSS 22.0 program was used while for the other two, a confirmatory factorial analysis (CFA) was performed using the AMOS IBM 22.0 program. In all cases, the values obtained are above the recommended limits, indicating scale reliability (see Table 1).

Discriminant validity analysis (see Table 2), performed by calculating the confidence intervals for the correlations between pairs of variables and by comparing the variance extracted and squared covariance between factors, showed that no pair of variables indicated a lack of discriminant validity, except for the pair of variables in the result for 'learning' and 'behavior'; in this case, the confidence interval for the correlation included the value one and the value of the variance extracted for 'behavior' was below the squared covariance between the two variables. Despite these results, it was decided to keep these two variables as distinct constructs in the analysis, given that they are considered to reflect theoretically different concepts.

Table 2

\section{Discriminant validity ${ }^{\mathrm{a}}$}

\begin{tabular}{|l|c|c|c|c|c|c|c|}
\hline & F1 (Coach) & $\begin{array}{c}\text { F2 } \\
\text { (Coachee) }\end{array}$ & $\begin{array}{c}\text { F3 } \\
\text { (Process) }\end{array}$ & $\begin{array}{c}\text { F4 } \\
\text { (Relationship) }\end{array}$ & $\begin{array}{c}\text { F5 } \\
\text { (Satisfaction) }\end{array}$ & $\begin{array}{c}\text { F6 } \\
\text { (Learning) }\end{array}$ & $\begin{array}{c}\text { F7 } \\
\text { (Behavior) }\end{array}$ \\
\hline F1 & 0.521 & 0.203 & 0.387 & 0.178 & 0.389 & 0.355 & 0.215 \\
\hline F2 & $(0.306,0.594)$ & 0.722 & 0.276 & 0.110 & 0.326 & 0.282 & 0.211 \\
\hline
\end{tabular}




\begin{tabular}{|l|l|c|c|c|c|c|c|}
\hline F3 & $(0.440,0.804)$ & $\begin{array}{c}(0.355, \\
0.695)\end{array}$ & 0.562 & 0.303 & 0.551 & 0.493 & 0.372 \\
\hline F4 & $(0.284,0.560)$ & $\begin{array}{c}(0.206, \\
0.458)\end{array}$ & $\begin{array}{c}(0.378, \\
0.722)\end{array}$ & 0.639 & 0.199 & 0.143 & 0.084 \\
\hline F5 & $(0.454,0.794)$ & $\begin{array}{c}(0.407, \\
0.735)\end{array}$ & $\begin{array}{c}(0.544, \\
0.940)\end{array}$ & $(0.300,0.592)$ & 0.729 & 0.582 & 0.392 \\
\hline F6 & $(0.405,0.753)$ & $\begin{array}{c}(0.363, \\
0.699)\end{array}$ & $\begin{array}{c}(0.496, \\
0.908)\end{array}$ & $(0.232,0.524)$ & $(0.565,0.961)$ & 0.715 & 0.701 \\
\hline F7 & $(0.310,0.618)$ & $\begin{array}{c}(0.303, \\
0.615)\end{array}$ & $\begin{array}{c}(0.418, \\
0.802)\end{array}$ & $(0.158,0.422)$ & $(0.448,0.804)$ & $\begin{array}{c}(0.617, \\
1.057)\end{array}$ & 0.659 \\
\hline
\end{tabular}

${ }^{*}$ Confidence intervals for the covariances $+/-2$ errors below, average variance extracted in the diagonal, and squared covariances above.

Source: Own work.

A confirmatory factor analysis (see Table 3) performed to assess the convergent validity of the measures indicated that all indicators load significantly and substantially on their respective constructs. The various measures of goodness of fit of the confirmatory factor model provide sufficient evidence that the results are an acceptable representation of the constructs.

Table 3

\section{Convergent validity: factorial loads ${ }^{\mathrm{a}}$}

\begin{tabular}{|c|c|c|c|c|c|}
\hline Variables & Indicators & $\begin{array}{l}\text { Non-standardized } \\
\text { coefficients }\end{array}$ & S. E. & C. R. & $\begin{array}{l}\text { Standardized } \\
\text { coefficients }\end{array}$ \\
\hline \multirow{3}{*}{ Coach } & V1 & 1.000 & --- & --- & 0.704 \\
\hline & $\mathrm{V} 2$ & $0.988 * * *$ & 0.082 & 11.991 & 0.727 \\
\hline & V3 & $1.042 * * *$ & 0.107 & 9.742 & 0.736 \\
\hline \multirow{2}{*}{ Coachee } & V4 & 1.000 & --- & --- & 0.804 \\
\hline & V5 & $0.905 * * *$ & 0.061 & 14.789 & 0.894 \\
\hline \multirow{3}{*}{ Process } & V6 & 1.000 & --- & --- & 0.857 \\
\hline & V7 & $0.847 * * *$ & 0.095 & 8.887 & 0.629 \\
\hline & V8 & $0.904 * * *$ & 0.081 & 11.143 & 0.745 \\
\hline \multirow{4}{*}{ Relationship } & V9 & $0.987 * * *$ & 0.096 & 10.290 & 0.808 \\
\hline & V10 & $1.114 * * *$ & 0.101 & 11.051 & 0.873 \\
\hline & V11 & $0.861 * * *$ & 0.086 & 9.985 & 0.784 \\
\hline & V12 & 1.000 & --- & --- & 0.726 \\
\hline \multirow{4}{*}{ Satisfaction } & V13 & 1.000 & --- & --- & 0.908 \\
\hline & V14 & $0.820 * * *$ & 0.067 & 12.311 & 0.730 \\
\hline & V15 & $0.851 * * *$ & 0.049 & 17.256 & 0.865 \\
\hline & V16 & $1.069 * * *$ & 0.056 & 19.070 & 0.901 \\
\hline \multirow{6}{*}{ Learning } & V17 & 1.000 & --- & --- & 0.864 \\
\hline & V18 & $0.905 * * *$ & 0.061 & 14.789 & 0.841 \\
\hline & V19 & $0.898 * * *$ & 0.066 & 13.507 & 0.799 \\
\hline & $\mathrm{V} 20$ & $0.933 * * *$ & 0.063 & 14.776 & 0.840 \\
\hline & $\mathrm{V} 21$ & $1.059 * * *$ & 0.070 & 15.229 & 0.855 \\
\hline & V22 & $0.998 * * *$ & 0.063 & 15.825 & 0.872 \\
\hline
\end{tabular}




\begin{tabular}{|c|c|c|c|c|c|}
\hline \multirow{5}{*}{} & V23 & 1.000 & --- & --- & 0.845 \\
\cline { 2 - 6 } & V24 & $0.851 * * *$ & 0.073 & 11.632 & 0.744 \\
\cline { 2 - 6 } & V25 & $0.942 * * *$ & 0.075 & 12.533 & 0.782 \\
\cline { 2 - 6 } & V26 & $1.074 * * *$ & 0.080 & 13.421 & 0.816 \\
\cline { 2 - 6 } & V27 & $1.064 * * *$ & 0.091 & 11.737 & 0.749 \\
\cline { 2 - 6 } & V28 & $1.019 * * *$ & 0.073 & 13.992 & 0.838 \\
\cline { 2 - 6 } & V29 & $1.043 * * *$ & 0.073 & 14.207 & 0.846 \\
\cline { 2 - 6 } & V30 & $1.114 * * *$ & 0.075 & 14.785 & 0.865 \\
\hline
\end{tabular}

"Overall model fit indices: $\chi^{2}(\mathrm{df}=379)=678.020, \mathrm{p}=0.000, \chi^{2} / \mathrm{df}=1.789$, comparative fit index $[\mathrm{CFI}]=0.936$, goodness-of-fit index $[\mathrm{GFI}]=0.807$, root mean square error of approximation $[\mathrm{RMSEA}]=0.067,{ }^{* * *} \mathrm{p}<.001$. Source: Own work.

\section{RESULTS}

\subsection{Descriptive results}

In general, the average ratings observed in all indicators are very high, as Table 1 shows; all averages are above 5 on a scale from 1 to 7 . The average ratings of the variables confirm that coachees rated the perceived coach-coachee relationship $(m=6.214$, SD $=0.774)$ highest, followed by perceived coach's performance $(\mathrm{m}=6.097, \mathrm{SD}=0.822)$, perceived coachee's readiness $(\mathrm{m}=6.026, \mathrm{SD}=0.909)$, coachee satisfaction $(\mathrm{m}=5.925$, $\mathrm{SD}=0.880)$, perceived learning $(\mathrm{m}=5.790, \mathrm{SD}=0.980)$, perceived coaching process $(\mathrm{m}$ $=5.514, \mathrm{SD}=1.002)$, and perceived behavioral change $(\mathrm{m}=5.343, \mathrm{SD}=0.991)$. It is also worth noting the high score given by coachees to the variables in the constructs of results - satisfaction, and to a lesser extent, learning and behavioral change.

\subsection{Hypothesis test: path analysis}

To test the study hypotheses, the composite measures for each measurement scale were calculated as the average of all its indicators. These new variables were included in a path analysis, performed using the AMOS IBM 22.0 program, in which all the relations considered in formulating the hypotheses were estimated. The modification indexes suggested that a relation should be introduced that had not initially been considered, between the 'behavior' and 'learning' variables.

The results of the final model indicate a good model fit with the data (see Table 4). The multivariate kurtosis estimation from the Mardia (1970) coefficient indicate an extreme positive score (Multivariate kurtosis, Mardia coefficient $=50.51$ ), questioning the fact that variables are distributed multinormally. For this reason, in addition to the standardized and non-standardized coefficients, the confidence intervals for the non-standardized coefficients obtained by the bootstrapping procedure are indicated. This technique is a widely accepted way of addressing the problem of non-normal multivariate data (Wentzel 2012).

The (standardized) coefficients estimated confirm that the 'behavior' variable is positively and significantly related to 'satisfaction' ( $b=0.427, p<0.001)$, thus supporting Hypothesis 1 . The 'coachee' variable (perceived coachee's readiness) is also positively and 
significantly related to 'satisfaction' $(\mathrm{b}=0.319, \mathrm{p}<0.001)$, supporting Hypothesis 2 . The results also support Hypothesis 3, since 'process' (perceived process of coaching developed) is also positively and significant related to 'satisfaction' ( $b=0.217, p<0.001)$. The analysis showed that the relation between the 'relationship' and 'satisfaction' variables was not significant $(b=0.023, p>0.1)$. Hypothesis 4 is therefore not supported.

Table 4

\section{Structural model. Standardized and non-standardized coefficients}

\begin{tabular}{|c|c|c|c|c|c|}
\hline \multirow[b]{2}{*}{ Relation/Effect } & \multicolumn{4}{|c|}{ Path analysis $1^{\mathrm{a}}$} & \multirow{2}{*}{ 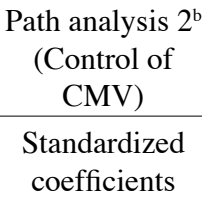 } \\
\hline & $\begin{array}{l}\text { Non-standardized } \\
\text { coefficients }\end{array}$ & S. E. & C. R. & $\begin{array}{c}\text { Standardized } \\
\text { coefficients }\end{array}$ & \\
\hline Coach $\rightarrow$ Satisfaction & $\begin{array}{c}0.458 * * * \\
(0.306,0.599)^{\mathrm{c}}\end{array}$ & 0.067 & 6.839 & 0.427 & 0.409 \\
\hline Coachee $\rightarrow$ Satisfaction & $\begin{array}{c}0.309 * * * \\
(0.205,0.422)\end{array}$ & 0.050 & 6.164 & 0.319 & 0.314 \\
\hline Process $\rightarrow$ Satisfaction & $\begin{array}{c}0.190 * * * \\
(0.094,0.294)\end{array}$ & 0.050 & 3.780 & 0.217 & 0.238 \\
\hline Relationship $\rightarrow$ Satisfaction & $\begin{array}{c}0.027 \\
(-0.090,0.198)\end{array}$ & 0.061 & 0.435 & 0.023 & 0.030 \\
\hline Satisfaction $\rightarrow$ Learning & $\begin{array}{c}0.715 * * * \\
(0.578,0.876) \\
\end{array}$ & 0.084 & 8.511 & 0.643 & 0.622 \\
\hline Coach $\rightarrow$ Learning & $\begin{array}{c}0.233 * \\
(0.084,0.379)\end{array}$ & 0.090 & 2.588 & 0.195 & 0.210 \\
\hline Learning $\rightarrow$ Behavior & $\begin{array}{c}0.848 * * * \\
(0.774,0.936)\end{array}$ & 0.042 & 20.363 & 0.839 & 0.807 \\
\hline \multicolumn{6}{|l|}{ Covariance/Correlation } \\
\hline Coach $\bullet \rightarrow$ Coachee & $\begin{array}{c}0.495 * * * \\
(0.371,0.663)\end{array}$ & 0.067 & 7.329 & 0.665 & 0.662 \\
\hline Coach $\leftarrow \rightarrow$ Process & $\begin{array}{c}0.578 * * * \\
(0.457,0.726)\end{array}$ & 0.076 & 7.626 & 0.705 & 0.708 \\
\hline Coachee $\leftarrow \rightarrow$ Process & $\begin{array}{c}0.526 * * * \\
(0.402,0.677)\end{array}$ & 0.079 & 6.642 & 0.581 & 0.585 \\
\hline Process $\leftrightarrow \rightarrow$ Relationship & $\begin{array}{c}0.502 * * * \\
(0.394,0.647)\end{array}$ & 0.070 & 7.212 & 0.650 & 0.660 \\
\hline Coach $\leftarrow \rightarrow$ Relationship & $\begin{array}{c}0.422 * * * \\
(0.322,0.556)\end{array}$ & 0.058 & 7.342 & 0.667 & 0.658 \\
\hline Coachee $\leftarrow \rightarrow$ Relationship & $\begin{array}{c}0.372 * * * \\
(0.293,0.466)\end{array}$ & 0.060 & 6.203 & 0.531 & 0.531 \\
\hline
\end{tabular}

a Overall model fit indices: $\chi^{2}(\mathrm{df}=6)=13.535, \mathrm{p}=0.095, \chi^{2} / \mathrm{df}=1.692$, comparative fit index $[\mathrm{CFI}]=0.994$, goodness-of-fit index $[\mathrm{GFI}]=0.979$, root mean square error of approximation $[\mathrm{RMSEA}]=0.063$.

${ }^{\mathrm{b}}$ Overall model fit indices: $\chi^{2}(\mathrm{df}=8)=15.189, \mathrm{p}=0.056, \chi^{2} / \mathrm{df}=1.899$, comparative fit index $[\mathrm{CFI}]=0.993$, goodnessof-fit index $[\mathrm{GFI}]=0.978$, root mean square error of approximation $[\mathrm{RMSEA}]=0.072, * \mathrm{p}<0.05$; $* * * \mathrm{p}<0.001$.

c $90 \%$ bootstrap confidence intervals (bias-corrected percentile method).

Source: Own work. 
The results also suggest that 'satisfaction' has a positive relation to 'learning' $(0.643$, $\mathrm{p}<0.001)$ and that this variable, in turn, has a positive relation to 'behavior' $(0.839, \mathrm{p}$ $<0.001)$. This supports Hypotheses 5 and 6. Interestingly, a direct relation that was not initially considered was observed between the 'coach' and 'learning' variables $(0.195, \mathrm{p}<$ $0.05)$. The results obtained through the bootstrap procedure substantially and similarly support the proposed model, by obtaining positive confidence intervals for all relationships, except for the relationship between the'relationship' and'satisfaction' variables.

A second path analysis was performed to check common method variance (CMV). In this case, the composite variables were calculated using the factor loadings resulting from a CFA in which a common latent factor was added to capture the CMV. As Table 4 shows, control of the CMV did not alter the results of the hypotheses and the new standardized coefficients vary very little from those previously obtained.

\section{DISCUSSION}

This study shows the influence exercised by the 'coach', and to a lesser extent, the 'coachee' and the 'process', on coachee 'satisfaction'. In contrast with the hypothesized model, the results of this work also suggest that perceived coach's performance (commitment, communication skill and capacity to generate trust) form a construct that is capable of influencing learning directly even when the EC experience eventually turns out not to be particularly satisfying for the coachee. EC is characterized by its intensive assessment of and feedback on events, with a view to achieving a specific increase in self-awareness (learning). These results are in line with various studies confirming the positive impact of coaching on executives' self-efficacy (CompassPoint 2003; Finn et al. 2007; Kombarakaran et al. 2008; Baron and Morin 2009b).

The literature identifies 'relationship' as the most important factor because of its contribution to the effectiveness of the intervention (De Haan et al. 2016). This study shows a strong presence of this variable in practically all processes for which information is available. Its presence may therefore be deduced to be inherent to any successful EC intervention. However, unlike the hypothesized model used as the starting point here, the resulting model shows that the effect of the 'relationship' construct is not statistically significant. Nonetheless, 'relationship' has the highest score of all those analyzed, and its dispersion in the responses is the lowest, showing a great consistency in the coachees' responses in this regard. Discriminant validity can be seen between the variables, so the possibility of the effect being absorbed by the other factors can be ruled out. It is in some way related to the other variables, in terms of both factors and results, but that 'relationship' is not as strong as the one reflected by the 'coach', 'coachee' and 'process' factors. One possible explanation for this low explanatory capacity of the 'relationship' variable is that it behaves in a similar fashion to a constant (very low dispersion of responses, combined with a very high rating). We therefore agree with the findings of studies by Boyce et al. (2010), De Haan et al. (2013) and De Haan et al. (2016) that the 'relationship' variable is critical or essential for a satisfactory executive coaching process (given the high score awarded by the participants). However, we do not find it to be predictive for the dependent variables (the coaching results), at least amongst the sample used in this study. 
Based on the results, it seems advisable to consider using Kirkpatrick's model (1975) as a tool for summative evaluation of the results of EC. Despite criticisms levelled against this model (Alliger and Janak 1989; Holton 1996; Giangreco et al. 2010; Colquitt et al. 2012), principally based on an assumption of the causal linkages between the different types of results analyzed, our results show the great intensity of the relationship between 'satisfaction' and 'learning', and between 'learning' and change in 'behavior'. On the one hand, satisfaction appears to be a mediating condition for executives to feel more capacitated (i.e. to learn) and subsequently to change their behavior, as Kirkpatrick (1975) proposed in his model. Although the mediating effect of coachee 'satisfaction' is not directly considered or tested in any formal way in this study, its central place in the model and the proposed hypotheses do appear to indicate that this variable encompasses and transmits the effects of the 'coach', 'coachee', 'process' and 'relationship' factors to the coachee's 'learning'.

One possible explanation for this first mediation is that in coaching, satisfaction reflects the coachees' involvement, excitement, and opening-up in their own personal process, as well as the feeling of being listened to and valued at all times, with a subsequent lowering of their defensive barriers. Coaching is a process of profound reflection on delicate personal issues and it requires sincere, free and open analysis. Where prior satisfaction exists, the coachee is more likely to be predisposed to learning and to a change in behavior.

\section{CONCLUSIONS}

In this work the relationship between EC factors and results is analyzed from a coachee perspective, proving that coach, process and coachee all influence the coachee's satisfaction and, subsequently, their learning and behavioral changes, as Kirkpatrick's model (1975) indicates. Our results also show that appropriate action by the coach can impact the coachees' learning. This illustrates how important it is for HR professionals in charge of executive development programs to select experienced coaches. Our study provides empirical evidence that EC is an effective instrument for promoting learning and behavioral changes among executives. This technique should therefore be taken into consideration in management development processes.

This study makes various contributions to scientific research into EC, measuring the relative influence of different factors on the success of EC with a set of validated measurements. It also provides a model that reflects the impact of an EC intervention from the coachee's point of view. At the same time, the three levels of summative results obtained with implementation of EC appear to be related, as Kirkpatrick's (1975) conceptual model proposes. This is an advance on most previous studies and opens the way to subsequent research that can be developed using the same conceptual model in other contexts of EC application with a set of validated measurements.

The main limitations of the study lie in its cross-sectional nature and the fact that the sample is drawn from responses within a single cultural and geographical context. In addition, a larger sample of EC practitioners would have been desirable when assessing the content validity of the questionnaire. As for future research, apart from the need to overcome these limitations, it would be helpful to assess the possible existence of moderating and mediating effects in other variables, including support from management, and to test 
the possible mediating role exercised by the 'relationship' variable on the results of EC, in line with Baron and Morin (2009a) and Boyce et al. (2010).

\section{AKNOWLEDGEMENTS}

We wish to express our most sincere thanks to all the managers and coaches who collaborated in this research, either by answering the questionnaire, or through their active participation in the validation stages of the questionnaire, the pre-test and testing of results.

The authors received financial support for the research from the University of the Basque Country, University-Society grant (Ref.: US12/07), FESIDE foundation (Research grant, 2015) and the European Coaching School.

\section{REFERENCES}

Alliger, G. M. and Janak, E. A, 1989. Kirkpatrick's levels of training criteria: Thirty years later. Personnel Psychology, 42 (2), 331-342.

Alliger, G. M., Tannenbaum, S. L., Bennett, W., Traver, H. and Shotland, A., 1997. A meta-analysis of the relations among training criteria. Personnel Psychology, 50 (2), 341-358.

Bachkirova, T., Sibley, J. and Myers, A., 2015. Developing and applying a new instrument for microanalysis of the coaching process: The Coaching Process Q-Set. Human Resource Development Quarterly, 26 (4), 431-462.

Baron, L. and Morin, L., 2009a. The coach-coachee relationship in executive coaching: A field study. Human Resource Development Quarterly, 20 (1), 85-106.

Baron, L. and Morin, L., 2009b. The impact of executive coaching on self-efficacy related to management soft-skills. Leadership \& Organization Development Journal, 31 (1), 18-38.

Bates, R., 2004. A critical analysis of evaluation practice: the Kirkpatrick model and the principle of beneficence. Evaluation and Program Planning, 27 (3), 341-347.

Blackman, A.; Moscardo, G. and Gray, D. E., 2016. Challenges for the theory and practice of business coaching: A systematic review of empirical evidence. Human Resource Development Review, 15 (4), 459-486.

Boyce, L. A., Jackson, R. J. and Neal, L. J., 2010. Building successful leadership coaching relationships. Journal of Management Development, 29 (10), 914-931.

Bozer, G., Sarros, J. C. and Santora, J. C., 2014a. Academic background and credibility in executive coaching effectiveness. Personnel Review, 43 (6), 881-897.

Bozer, G., Sarros, J. C. and Santora, J. C., 2014b. Executive coaching: Guidelines that work. Development and Learning in Organizations: An International Journal, 28 (4), 9-14.

Carter, A., Blackman, A., Hicks, B., Williams, M. and Hay, R., 2017. Perspectives on effective coaching by those who have been coached. International Journal of Training and Development, 21 (2), 73-91.

Chen, G., Gully, S. M. and Eden, D., 2001. Validation of a new general self-efficacy scale. Organizational Research Methods, 4 (1), 62-83. 
Colquitt, J. A., LePine J. A. and Noe, R. A., 2000. Toward an integrative theory of training motivation: A meta-analytic path analysis of 20 years of research. Journal of Applied Psychology, 85 (5), 678-707.

CompassPoint Nonprofit Services. 2003. Executive Coaching Project: Evaluation of Findings. Harder Company Community Research, San Francisco, CA. Available at http:// www.compasspoint.org/sites/default/files/docs/research/6_execcoaching.pdf [consulted October 2016]

De Haan, E., Culpin, V. and Curd, J., 2011. Executive coaching in practice: what determines helpfulness for clients of coaching?. Personnel Review, 40 (1), 24-44.

De Haan, E., Duckworth, A., Birch, D. and Jones, C., 2013. Executive coaching outcome research: The contribution of common factors such as relationship, personality match, and self-efficacy. Consulting Psychology Journal: Practice and Research, 65 (1), 40-57.

De Haan, E., Grant, A.M., Burger, Y. and Eriksson, P-O., 2016. A large-scale study of executive and workplace coaching: The relative contributions of relationship, personality match, and self-efficacy. Consulting Psychology Journal: Practice and Research, 68 (3), 189-207.

Ellinger, A. D., Ellinger, A. E. and Keller, S. B., 2003. Supervisory coaching behavior, employee satisfaction, and warehouse employee performance: A dyadic perspective in the distribution industry. Human Resource Development Quarterly, 14 (4), 435-458.

Ely, K. and Zaccaro, S. J., 2011. Evaluating the effectiveness of coaching - A focus on stakeholders, criteria, and data collection methods. In G. Hernez-Broome and L. A. Boyce (Eds.), Advancing Executive Coaching: Setting the Course for Successful Leadership Coaching (pp. 319-349). San Francisco, CA: Jossey-Bass.

Ely, K., Boyce, L. A., Nelson, J. K., Zaccaro, S. J., Hernez-Broome, G. and Whyman, W., 2010. Evaluating leadership coaching: A review and integrated framework. The Leadership Quarterly, 21 (4), 585-599.

Feldman, D. C. and Lankau, M. J., 2005. Executive coaching: A review and agenda for future research. Journal of Management, 31 (6), 829-848.

Finn, F. A., Mason, C. M. and Bradley, L. M., 2007. Doing Well with Executive Coaching: Psychological and Behavioral Impacts. Academy of Management Conference, Philadelphia, PA. Available at http://eprints.qut.edu.au/10125/1/10125.pdf. [consulted July 2016]

Gan, G.C. and Chong, C. W., 2015. Coaching relationship in executive coaching: a Malaysian study. Journal of Management Development, 34 (4), 476-493.

Gessnitzer, S. and Kauffeld, S., 2015. The working alliance in coaching: why behavior is the key to success. The Journal of Applied Behavioral Science, 51 (2), 177-197.

Giangreco, A., Carugati, A. and Sebastiano, A., 2010. Are we doing the right thing? Food for thought on training evaluation and its context. Personnel Review, 39 (2), 162-177.

Grant, A. M., 2013. The efficacy of coaching. In J. Passmore, D. Peterson and T. Freire (Eds.), The Wiley-Blackwell Handbook of the Psychology of Coaching and Mentoring (pp. 15-37). Oxford: John Wiley and Sons.

Grover, S. and Furnham, A. 2016., Coaching as a developmental intervention in organizations: A systematic review of its effectiveness and the mechanisms underlying it. PLoS ONE, 11 (7), e0159137.

Gyllensten, K. and Palmer, S., 2006. Workplace stress: Can it be reduced by coaching. The Coaching Psychologist, 2 (1), 17-22. 
Hagen, M. S., and Peterson, S. L., 2014. Coaching scales a review of the literature and comparative analysis. Advances in Developing Human Resources, 16 (2), 222-241.

Hall, D. T., Otazo, K. L. and Hollenbeck, G. P., 1999. Behind closed doors: What really happens in executive coaching. Organizational Dynamics, 27 (3), 39-52.

Holton, E. F., 1996. The flawed four level evaluation model. Human Resource Development Quarterly, 7 (1), 5-21.

Jones, G. and Spooner, K., 2006. Coaching high achievers. Consulting Psychology Journal: Practice and Research, 58 (1), 40-50.

Jones, R. J., Woods, S. A. and Guillaume, Y. R. F., 2016. The effectiveness of workplace coaching: A meta-analysis of learning and performance outcomes from coaching. Journal of Occupational and Organizational Psychology, 89, 249-277.

Joo, B. K., 2005. Executive coaching: A conceptual framework from an integrative review of practice and research. Human Resource Development Review, 4 (4), 462-488.

Kilburg, R. R., 1997. Coaching and executive character: core problems and basic approaches. Consulting Psychology Journal: Practice and Research, 49 (4), 281-299.

Kilburg, R. R., 2001. Facilitating intervention adherence in executive coaching: A model and methods. Consulting Psychology Journal: Practice and Research, 53 (4), 251-267.

Kim, S., Egan, T. M. Kim, W. and Kim, J., 2013. The impact of managerial coaching behavior on employee work-related reactions. Journal of Business Psychology, 28 (3), 315-330.

Kirkpatrick, D. L., 1975. Evaluating Training Programs. Madison, WI: American Society for Training and Development.

Kombarakaran, F. A., Yang, J. A., Baker, M. N. and Fernandes, P. B., 2008. Executive coaching: it works!. Consulting Psychology Journal: Practice and Research, 60 (1), 78-90.

Kovacs, L. and Corrie, S., 2016. What can realist evaluation tell us about how coaching interventions work?. The Coaching Psychologist, 12 (2), 59-66.

Kraiger, K., Ford, J. K. and Salas, E., 1993. Application of cognitive, skill-based, and affective theories of learning outcomes to new methods of training evaluation. Journal of Applied Psychology, 78 (2), 311-328.

Lambert, M. J. and Barley, D. E., 2001. Research summary on the therapeutic relationship and psychotherapy outcome. Psychotherapy: Theory, Research, Practice, Training, 38 (4), 357-361.

Lewis-Duarte, M. and Bligh, M., 2012. Agents of 'influence': exploring the usage, timing, and outcomes of executive coaching tactics. Leadership \& Organization Development Journal, 33 (3), 255-281.

Lim, D. H. and Morris, M. L., 2006. Influence of trainee characteristics, instructional satisfaction, and organizational climate on perceived learning and training transfer. Human Resource Development Quarterly, 17 (1), 85-115.

Lopez, M.L., 2017. Do we need alliance factor definitions unique to coaching? Clients' operational definitions of research-based definitions. International Journal of Evidence Based Coaching and Mentoring, 15 (1), 42-64.

Luthans, F. and Peterson, S. J., 2003. 360 degree feedback with systematic coaching: Empirical analysis suggests a winning combination, Human Resource Management, 42 (3), 243-256. 
MacKie, D., 2014. The effectiveness of strength-based executive coaching in enhancing full range leadership development: A controlled study. Consulting Psychology Journal: Practice and Research, 66 (2), 118-137.

Mardia, K. V. (1970). Measures of multivariate skewness and kurtosis with applications. Biometrika, 57(3), 519-530.

Noe, R. A. and Wilk, S. L., 1993. Investigation of the Factors that Influence Employees Participation in Development Activities. Journal of Applied Psychology, 78 (2), 291-302.

Olivero, G., Bane, K. D. and Kopelman, R. E., 1997. Executive coaching as a transfer of training tool: Effects on productivity in a public agency. Public Personnel Management, 26 (4), 461-469.

Osatuke, K., Yanovsky, B., and Ramsel, D., 2017. Executive coaching: New framework for evaluation. Consulting Psychology Journal: Practice and Research, 69 (3), 172-186.

Passmore, J. and Fillery-Travis, A., 2011. A critical review of executive coaching research: a decade of progress and what's to come. Coaching: An International Journal of Theory, Research and Practice, 4 (2), 70-88.

Pershing, J. A. and Pershing, J. L., 2001. Ineffective reaction evaluation. Human Resource Development Quarterly, 12 (1), 73-90.

Rekalde, I., Landeta, J. and Albizu, E., 2015. Determining factors in the effectiveness of executive coaching as a management development tool. Management Decision, 53 (8), 1677-1697.

Rekalde, I., Landeta, J., Albizu, E. and Fernández-Ferrín, P., 2017. Is executive coaching more effective than other management training and development methods?. Management Decision, 55 (10), 2149-2162.

Rhoades, L. and Eisenberger, R., 2002. Perceived organizational support: A review of the literature. Journal of Applied Psychology, 87 (4), 698-714.

Russ-Eft, D. F., Dickinson, P. D. and Levine, R., 2005. Instructor quality affecting emergency medical technician (EMT) preparedness: a LEADS project. International Journal of Training and Development, 9 (4), 256-70.

Sitzmann, T., Brown, K. G., Casper, W. J., Ely, K. and Zimmerman, R. D., 2008. A review and meta-analysis of the nomological network of trainee reactions. Journal of Applied Psychology, 93 (2), 280-95.

Smither, J. W., London, M., Flautt, R., Vargas, Y. and Kucine, I., 2003. Can working with an executive coach improve multi-source feedback ratings over time? A quasi-experimental field study. Personnel Psychology, 56 (1), 23-44.

Stajkovic, A. D. and Luthans, F., 1997. A meta-analysis of the effects of organizational behavior modification on task performance, 1975-1995. Academy of Management Journal, 40 (5), 1122-1149.

Thach, E. 2002., The impact of executive coaching and 360 feedback on leadership effectiveness. Leadership \& Organization Development Journal, 23 (4), 205-214.

Theeboom, T., Beersma, B. and Van Viansen, A. E. M., 2014. Does coaching work? A meta-analysis on the effects of coaching on individual level outcomes in an organizational context. The Journal of Positive Psychology, 9 (1), 1-18.

Tracey, J. B., Hinkin, T. R., Tannenbaum, S. and Mathieu, J. E., 2001. The influence of individual characteristics and the work environment on varying levels of training outcomes. Human Resource Development Quarterly, 12 (1), 5-23. 
Tsai, P. C. F., Yen, Y. F., Huang, L. C. and Huang, I. C., 2007. A study on motivating employees learning commitment in the post-downsizing era: Job satisfaction perspective. Journal of World Business, 42 (2), 157-169.

Wasylyshyn, K. M., 2003. Executive coaching: An outcome study. Consulting Psychology Journal: Practice and Research, 55 (2), 94-106.

Wentzel, J, 2012. Modelling financial services adoption through an intermediary in South Africa: TAM and SEM approach. Unpublished PhD thesis, University of Pretoria. 